DOI https://doi.org/10.30525/978-9934-588-81-5-1.14

\title{
АНАЛІЗ КЛІНІЧНИХ СПОСТЕРЕЖЕНЬ ЛІКУВАННЯ ПАХВИННИХ ГРИЖ У ДІТЕЙ
}

\author{
Гаврилюк А. В. \\ аспірант кафедри дитячої хірургї
}

Вінницький національний медичний університет імені М. І. Пирогова

Конопліцький В. С.

доктор медичних наук, професор, завідувач кафедри дитячої хірургї

Вінницький національний медичний університет імені М. I. Пирогова м. Вінниця, Украӥна

Вступ. Розповсюдженість пахвинних гриж в дитячій популяції, за даними вітчизняних та закордонних дослідників складає від 0,8 до $4,4 \%$, та $є$ найбільш частою вродженою патологією в практиці дитячого хірурга, досягаючи 70-85\% від всіх гриж дитячого віку [1, с. 61; 2, с. 48]. Такий високий рівень захворюваності обумовлений анатомофізіологічними особливостями розвитку статевих органів хлопчиків. Основними критеріями діагностики пахвинних гриж у дітей залишаються об'єктивне обстеження та ультразвукова діагностика пахвинних ділянок [2, с. 49].

Негативний вплив пахової грижі на статеву залозу обумовлений постійною стискаючою дією на орган вмістом грижового мішка. Стає зрозумілим, що пізня діагностика вродженої вади дитини $є$ більш небезпечною для збереження функціональної спроможності яєчка в майбутньому [3, с. 58]. Тому діагностику та лікування пахової грижі бажано проводити у найкоротші терміни.

Мета роботи: підвищення якості обстеження та оперативного лікування дітей з пахвинними грижами.

Матеріали та методи. У дитячому хірургічному відділенні на базі кафедри дитячої хірургії ВНМУ ім. М.І. Пирогова з 2008 по 2018 роки, знаходилось на лікуванні 3462 дітей із пахвинними грижами, хлопчиків 2510 (72,5\%), дівчат 952 (27,5\%). Лікування було проведено дітям усіх вікових груп і склало наступну структуру відповідно до віку: до 1 року 377 (10,9\%) дітей; 1-3 роки 1212 (35,01\%) дітей; 4-14 років 1780 (51,4\%) дітей; 15-18 років 93 (2,69\%) пацієнта.

Результати та обговорення. Більшість дітей госпіталізовані до дитячого хірургічного відділення у плановій черзі. У складних діагностичних випадках окрім фізикального обстеження було проведено 
ультразвукове дослідження пахової області з відповідної сторони. Оперативне втручання проводилося на наступний день після госпіталізації. Хірургічна корекція патології проводилася відкритим методом, використовуючи грижесічення за методикою Дюамель I, II. Розподілення дітей для грижесічення методикою Дюамель I або II відбувалася враховуючи вік пацієнта.

32015 року в клініці запроваджено лапароскопічну герніорафію за методикою PIRS, яка була проведена у 112 пацієнтів, що склало $8,52 \%$ від усіх дітей за означений період. Лапароскопічна корекція проводилася із застосуванням загального знеболення 3 інтубацією трахеї та міорелаксацією. Хоча використання сучасних ендоскопічних технологій потребує застосування більш глибокого анестезіологічного забезпечення, однак ця методика дає можливість провести ревізію органів черевної порожнини з можливою діагностикою та одномоментним усуненням пахової грижі з протилежної сторони.

Операційний доступ пошарово ушивався з використанням шовного матеріалу Vicryl. Шкіра ушивалася в переважній більшості внутрішньошкірним швом за допомогою Рolyamide. Післяопераційний період у дітей протікав без ускладнень. Проводився щоденний туалет післяопераційної рани з обробкою шва розчинами антисептиків. Шви знімалися на 10-14 добу.

Висновки.

1. Лапароскопія, на відміну від відкритих методів грижесічення, зменшує до мінімуму можливість травмування сечового міхура та елементів сім'яного канатика.

2. Лапароскопічний метод лікування пахвинних гриж у дітей дозволяє візуалізувати контрлатеральне внутрішне пахвинне кільце та виконати одночасну корекцію вади з протилежної сторони за необхідності, що в свою чергу, попереджає виникнення метахромних гриж в катамнезі.

\section{Література:}

1. Переяслов А. А., Дворакевич А. О. Вибір методу лікування пахвинних гриж у новонароджених: що краще? Хірургія України. 2016. № 3. C. 61-66.

2. Притула В. П., Рибальченко І. Г. Діагностика та лікування пахвинно-калиткових гриж у новонароджених дітей. Патологія. 2015. № 2 (34). C. 48-51.

3. Квятковская Т. А., Квятковский Е. А. Гидроцеле. Монография. Днепропетровск: Герда. 2014. 196 с. 